\title{
Kualitas Air Danau Toba di Wilayah Kabupaten Toba Samosir dan Kelayakan Peruntukannya
}

\section{Water Quality of Toba Lake in the Region of Toba Samosir Regency and the Feasibility of Its Use}

\author{
YUDHI SOETRISNO GARNO, RUDI NUGROHO, MUHAMMAD HANIF \\ Pusat Teknologi Lingkungan, Badan Pengkajian dan Penerapan Teknologi \\ Gedung 820 Geostech, Kawasan Puspiptek Serpong, Tangerang Selatan, Banten \\ Email: yusoegarno@gmail.com
}

\begin{abstract}
This research was conducted to determine the status of Lake Toba water quality in the area of Toba Samosir (Tobasa) Regency and the feasibility of its use. This study revealed that BOD, COD, iron and free $\mathrm{Cl}_{2}$ of Lake Toba Tobasa regency exceed water quality criteria for Class I and Class II based on Governor Decree No. 1 Year 2009 on Raw water quality of Lake Toba in North Sumatera. High COD and $B O D$ values imply that Lake Toba water was polluted by organic matter presumably originated from floating net cages (KJA), while free $\mathrm{Cl}_{2}$ is thought to originate from domestic waste activities in Parapat City and its surroundings. In general, it was concluded that the water of Lake Toba in the Tobasa Regency did not meet the criteria for clean water and water tourism.
\end{abstract}

Keywords: Lake Toba, raw water, pollution, water quality

\begin{abstract}
ABSTRAK
Penelitian ini dilakukan untuk mengetahui kualitas air Danau Toba wilayah Kabupaten Toba Samosir (Tobasa) dan kelayakan peruntukannya. Penelitian ini mengungkapkan bahwa air Danau Toba wilayah Kabupaten Tobasa memiliki BOD, COD dan konsentrasi besi dan $\mathrm{Cl}_{2}$ bebas melebihi kriteria mutu air Kelas I dan Kelas II pada Peraturan Gubernur Sumatra Utara No 1 Tahun 2009. Tingginya nilai COD dan BOD mengisyaratkan bahwa perairan Danau Toba tercemar oleh bahan organik yang diduga berasal keramba jaring apung $(\mathrm{KJA})$, sedangkan $\mathrm{Cl}_{2}$ bebas diduga berasal dari limbah domestik kegiatan Kota Parapat dan sekitarnya. Secara umum disimpulkan bahwa air Danau Toba di wilayah Kabupaten Tobasa tidak/belum memenuhi kriteria untuk air baku air minum dan wisata air.
\end{abstract}

Kata kunci: danau Toba, bahan baku air, pencemaran, baku mutu

1. PENDAHULUAN.

1.1 Latar Belakang

Danau Toba yang terletak di Provinsi Sumatera Utara memiliki luas permukaan 1.124 $\mathrm{km}^{2}$ (112.400 ha), volume danau sekitar 256,2 $\mathrm{km}^{3}\left(256,2 \times 10^{9} \mathrm{~m}^{3}\right)$ dan kedalaman maksimum $508 \mathrm{~m}^{(1)}$. Dengan karakteristik fisik seperti itu maka Danau Toba menjadi danau terbesar di Indonesia, bahkan Asia Tenggara. Danau Toba terletak pada posisi geografi ${ }^{\circ} 2^{\circ} 41^{\prime} \mathrm{N} 98^{\circ} 53^{\prime} \mathrm{E}$

I $\quad 2.68^{\circ} \mathrm{N} 98.88^{\circ} \mathrm{E}$ dengan ketinggian 995 diatas permukaan laut. Dasar danau sebagian besar terdiri atas batu-batuan dan pasir. Pada bagian tertentu terdapat endapan lumpur dan daerah sekitar Danau Toba dikelilingi oleh perbukitan (2). Di tengah danau terdapat 5 pulau, yakni Pulau Samosir (Kabupaten. Samosir), Pulau Sibandang (Kabupaten Taput), Pulau Tulas (Kabupaten Samosir), Pulau Tolping (Kabupaten Dairi) dan Pulau Tao (Kabupaten Samosir).
Volume air yang sangat besar dan luas tersebut menjadikan Danau Toba memiliki potensi yang multi guna, seperti pembangkit tenaga listrik, budidaya perikanan, bahan baku air bersih, wisata dan transportasi. Saat ini berbagai potensi tersebut telah dimanfaatkan secara bersamaan; namun karena dilaksanakan secara sektoral (belum terpadu), dengan rencana pengembangan sendiri-sendiri maka keberhasilan sektor yang satu (akan) dapat menyebabkan hilangnya potensi sektor yang lain. Sebagai contoh, telah diakui bahwa budidaya ikan dengan Keramba Jaring Apung (KJA) dapat berkembang dengan baik dan telah terbukti mampu meningkatkan pendapatan masyarakat sekitar. Perkembangan KJA yang sangat pesat dan tidak mengindahkan daya dukung dan daya tampung badan air telah menghasilkan limbah organik yang berlebihan. Dampak dari limbah organik yang berlebihan tersebut adalah penurunan oksigen terlarut karena digunakan untuk dekomposisi, dan 
timbulnya $\mathrm{H}_{2} \mathrm{~S}$, amoniak, dan peningkatan nutrien ( $\mathrm{N}$ dan $\mathrm{P}$ ) sebagai hasil dekompisisi.

Penurunan oksigen terlarut (DO), peningkatan konsentrasi $\mathrm{H}_{2} \mathrm{~S}$ dan Amoniak jelas mengganggu kehidupan biota perairan, termasuk ikan; sedangkan peningkatan nutrien (eutrofikasi) dapat memicu terjadinya algaebloom (ledakan populasi alga) dan kematian ikan secara massal. Algae bloom adalah ledakan pertumbuhan alga dalam waktu yang singkat, sehingga air menjadi hijau pekat, dan karena pada umumnya terjadi pada blue green algae yang mengeluarkan lendir maka perairan menjadi lengket menjijikan. Kondisi tersebut akan semakin parah karena algae bloom biasanya diikuti oleh kematian ikan yang ada dalam badan air tersebut, baik ikan liar maupun ikan budidaya. Jika kondisi seperti ini terjadi maka dapat dipastikan tidak akan ada wisatawan yang mau datang atau dengan kata lain potensi pariwisata danau tersebut telah hilang. Fenomena seperti itu tidak boleh terjadi di Danau Toba, apalagi sejak tahun 2011 kawasan Toba dan sekitarnya telah ditetapkan sebagai kawasan strategis pariwisata nasional (KSPN) melalui Peraturan Pemerintah (PP) Nomor 50 Tahun 2011 tentang Rencana Induk Kepariwisataan Nasional Tahun 2010-2025.

Berkenaan dengan penetapan KSPN tersebut, maka kawasan Toba dan sekitarnya kini memiliki fungsi utama pariwisata atau potensi pengembangan pariwisata. Dalam rangka menindaklanjuti KSPN tersebut, kini beberapa daerah otonomi telah merencanakan pengembangan kawasan wisata di wilayahnya masing-masing, seperti Kabupaten Toba Samosir (Tobasa) yang membangun Kawasan Ekonomi Khusus (KEK) Pariwisata Sibisa, Kabupaten Tapanuli Utara yang akan membangun KEK pariwisata di Moeara dan Kabupaten Humbang Hasundutan (humbas) berencana membangun KEK Pariwisata di tepian Danau Toba yang ada di wilayahnya; serta akan disusul daerah-daerah otonom lainnya.

Kesuksesan pengembangan kawasan Danau Toba dan sekitarnya menjadi destinasi wisata akan sangat dipengaruhi oleh kualitas air danau Toba, baik secara keseluruhan maupun per wilayah otonom. Hal ini disebabkan karena wisatawan memerlukan sumber air baku untuk air bersih yang tidak sedikit dan perairan Toba yang tidak tercemar. Untuk itulah maka perlu diketahui status kualitas air dan kelayakan air Danau Toba saat ini.

\subsection{Tinjauan Pustaka}

Selama ini berbagai kegiatan ekonomi di kawasan Danau Toba dan sekitarnya telah dilakukan dengan intensif, baik di wilayah daratan (pertanian, perkebunan, peternakan, domestik dan industri) maupun di wilayah perairan (perhubungan, perikanan budidaya, perikanan tangkap, dan lainnya). Berbagai kegiatan tersebut dipastikan telah menghasilkan limbah, yang pada akhirnya akan masuk ke Danau Toba. Sampai saat ini kegiatan-kegiatan di kawasan Danau Toba dan sekitarnya didominasi oleh penghasil limbah organik, sehingga meskipun ada penghasil limbah nonorganik, termasuk logam berat namun karena volume danau yang sangat besar, maka pengaruhnya terhadap perubahan kualitas air sulit teridentifikasi sehingga publikasi tentang limbah yang mengandung logam berat sangat minim.

Masuknya berbagai limbah dari berbagai kegiatan tersebut menyebabkan peningkatan konsentrasi fosfor dan nitrogen terlarut. Laporan yang ada mengungkapkan bahwa konsentrasi $\mathrm{PO}_{4}$-fosfor pada tahun 2016 tercatat $0,05 \mathrm{mg} / \mathrm{l}$ naik 10 kali dari konsentrasi fosfat pada 1929 yang hanya $0,005 \mathrm{mg} / /^{(3)}$. Sementara itu konsentrasi nitrogen dilaporkan terukur pada kisaran 0,350-650 mg/l. Konsentrasi kedua nutrien tersebut diduga menjadi penyebab terjadinya peningkatan kesuburan perairan (eutrofikasi) Danau Toba.

Peningkatan kedua jenis hara tersebut dimanfaatkan dengan baik oleh fitoplankton untuk pertumbuhannya. Hal ini terindikasikan pada terjadinya peningkatan nilai konsentrasi klorofil a yang pada periode Februari-Agustus 2016 terukur 0,012 mg/l; yang mengindikasikan bahwa perairan Danau Toba telah masuk kelas mesotrofik padahal pada akhir 2014 dilaporkan masih tergolong pada kelas ultraoliogotrofik.

Selain terjadi perubahan tingkat kesuburan dari ultraoliogotrofik menjadi mesotrofik, telah terjadi pula perubahan pada algae-bloom kejernihan air (secchi depth) Danau Toba, dimana pada 1930 dilaporkan berkisar antara 7,5-11,5 m, berubah menjadi $6 \mathrm{~m}$ pada 2014 . Perubahan ini mengisyaratkan bahwa perairan Danau Toba menjadi semakin keruh. Kekeruhan air berhubungan erat dengan organic tersuspensi dan terlarut, yang untuk mendekomposisinya memerlukan oksigen terlarut (DO). Penggunaan DO untuk dekomposisi tersebutlah yang menyebabkan terjadinya perubahan DO Danau Toba dari waktu ke waktu. Saat ini konsentrasi DO di kedalaman $\geq 150 \mathrm{~m}$ tercatat di bawah $0.5 \mathrm{mg} / \mathrm{l}$ padahal pada 1929 DO di kedalaman tersebut dilaporkan antara 5.35-5.40 mg//(3).

Uraian tersebut diatas mengarahkan kita untuk menyimpulkan bahwa perubahan kualitas perairan Danau Toba dipicu oleh peningkatan nutrien, yang merupakan limbah dari berbagai kegiatan yang ada selama ini. Publikasi yang 
ada mengungkapkan bahwa hara terlarut di perairan Danau Toba yang menyebabkan terjadinya perubahan kualitas perairan adalah berasal dari KJA sebesar $66 \% \mathrm{~N}$ dan $50 \% \mathrm{P}$; limbah domestik (rumah tangga) sebesar $21 \% \mathrm{~N}$, dan $17 \% \mathrm{P}$; dan dari peternakan sebesar $7 \% \mathrm{~N}$ dan $3 \% \mathrm{P}^{(3)}$..

Publikasi lainnya mengukur konsentrasi logam berat di perairan Danau Toba di 3 lokasi, yakni (a) di salah satu inlet Danau Toba yaitu di Ajibata, Kabupaten Toba Samosir; (b) di keramba jaring apung yang berada di daerah Haranggaol Horison, Kabupaten Simalungun, dan (c) di outlet Danau Toba yang berada di daerah Porsea, Kabupaten Asahan. Laporan tersebut mengungkapkan bahwa konsentrasi $\mathrm{Cu}$ di inlet Danau Toba berkisar antara 0,026-0,027 $\mathrm{mg} / \mathrm{L}$; di keramba jaring apung Harangggaol antara 0,022-0,029 mg/l, dan di outlet Danau Toba antara 0,020-0,045 mg/l. Sementara itu konsentrasi $\mathrm{Pb}$ di inlet Danau Toba berkisar antara 0,033-0,044 mg/l; di keramba jaring apung Harangggaol berkisar antara 0,013-0,014 $\mathrm{mg} / \mathrm{l}$, dan di outlet Danau Toba berkisar antara 0,029-0,030 mg/l (4).

\subsection{Tujuan.}

Penelitian ini dilakukan dengan tujuan untuk mengetahui status kualitas air Danau Toba wilayah Kabupaten Toba Samosir dan kelayakan peruntukannya.

\section{BAHAN DAN METODE.}

\subsection{Pengumpulan sampel.}

Penelitian ini dilakukan dengan cara mengambil sampel di 3 lokasi di Danau Toba, wilayah Kabupaten Toba Samosir (Tobasa), dan

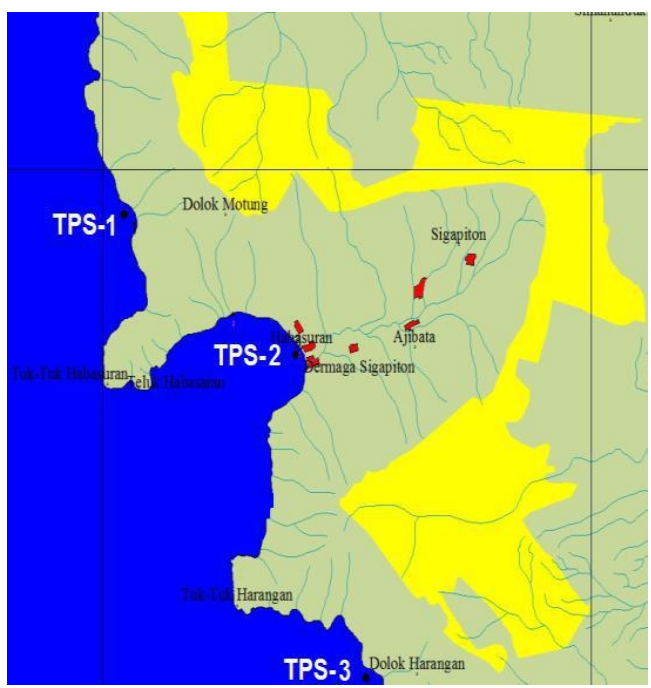

Gambar 1. Tempat Pengambilan Sampel (TPS)

\begin{tabular}{|c|c|c|c|}
\hline Posisi & TPS-1 & TPS-2 & TPS-3 \\
\hline LU & 02 35'56,2” & $0235^{\prime} 16,5^{\prime \prime}$ & $0236^{\prime} 09,33^{\prime \prime}$ \\
\hline BT & $9855^{\prime} 42,5^{\prime \prime}$ & $9855^{\prime} 21,2 "$ & $98466^{\prime} 46,4^{\prime \prime}$ \\
\hline
\end{tabular}

melakukan pengamatan in-situ meliputi pengukuran temperatur air, kekeruhan dan $\mathrm{pH}$. Temperatur udara diukur dengan termometer air raksa, sedangkan temperatur air, dan konduktivitas diukur dengan SCT-meter. Untuk analisis laboratorium guna mendapatkan data parameter kimia dan biologi, sampel air dari kedalaman 0-15 cm diambil dengan menggunakan water kammerer sampler, kemudian diawetkan dan dibawa ke laboratorium "Global Quality Analitical" Bogor untuk dianalisa.

\subsection{Analisis sampel.}

Di laboratorium sampel air dianalisis dengan metode seperti yang disajikan pada Tabel-1.

Tabel-1. Daftar alat dan metode yang digunakan untuk menganalisa sampel.

\begin{tabular}{|c|c|c|}
\hline Parameter & Unit & $\begin{array}{c}\text { Metoda } \\
\text { Analisis } \\
\end{array}$ \\
\hline Suhu air & ${ }^{0} \mathrm{C}$ & elektrometri \\
\hline Warna & PtCo & kolorimetrik \\
\hline Bau-Rasa & Orgipto & organoleltik \\
\hline $\mathrm{DHL}$ & Um/cm & Konduktifiti \\
\hline Salinitas & $0 / 00$ & Konduktifiti \\
\hline $\begin{array}{l}\text { Suspensi } \\
\text { Padatan }\end{array}$ & $\mathrm{mg} / \mathrm{l}$ & \\
\hline Kekeruhan & NTU & Nephelometrik \\
\hline $\mathrm{pH}$ & & Elektrometrik \\
\hline Alkalinitas & $\mathrm{CaCO}_{3}$ & Titrimetrik \\
\hline Kesedahan & $\mathrm{m}$ & Titrimetrik \\
\hline $\begin{array}{l}\text { Oksigen } \\
\text { Terlarut }\end{array}$ & $\mathrm{mg} / \mathrm{l}$ & lod-Winkler \\
\hline BOD-5 hari & $\mathrm{mg} / \mathrm{l}$ & Winkler \\
\hline COD & $\mathrm{mg} / \mathrm{l}$ & Titrimetrik \\
\hline $\begin{array}{l}\text { Bilangan } \\
\text { Oksidasi } \\
\mathrm{KMnO}_{4}\end{array}$ & $\mathrm{mg} / \mathrm{l}$ & $\mathrm{Oks}_{-} \mathrm{KMnO}_{4}$ \\
\hline $\begin{array}{c}\text { Ammonium - } \\
\mathrm{NH}_{4}\end{array}$ & $\mathrm{mg} / \mathrm{l}$ & Indo-blue \\
\hline Nitrit $\mathrm{NO}_{2}-\mathrm{N}$ & $\mathrm{mg} / \mathrm{l}$ & Spect.-Diazo \\
\hline Nitrat $\mathrm{NO}_{3}$ & $\mathrm{mg} / \mathrm{l}$ & Brucinum \\
\hline Sulfat $\mathrm{SO}_{4}$ & $\mathrm{mg} / \mathrm{l}$ & Spect-BaCl 2 \\
\hline $\begin{array}{l}\text { Ortho Posfat } \\
\mathrm{PO}_{4}\end{array}$ & $\mathrm{mg} / \mathrm{l}$ & \\
\hline Silikat $\mathrm{SIO}_{2}$ & $\mathrm{mg} / \mathrm{l}$ & $\mathrm{NA}_{2} \mathrm{MoO}_{4}$ \\
\hline $\begin{array}{l}\text { Sulfida } \mathrm{H}_{2} \mathrm{~S}- \\
\mathrm{S}\end{array}$ & $\mathrm{mg} / \mathrm{l}$ & Spect-NNDPD \\
\hline $\begin{array}{l}\text { Minyak- } \\
\text { Lemak } \\
\end{array}$ & $\mathrm{mg} / \mathrm{l}$ & Gravimetric \\
\hline Detergen & MBAS & Methilenblue \\
\hline Logam-berat & $\mathrm{mg} / \mathrm{l}$ & AAS \\
\hline
\end{tabular}




\section{HASIL DAN PEMBAHASAN.}

Hasil pengukuran dan analisis air Danau Toba selama penelitian disajikan pada Tabel-2. Sesuai tujuan peneltian yakni untuk mengetahui status kualitas dan kelayakan peruntukan air maka hasil studi ini dibahas dalam hubungannya dengan kesuburan air dan ketentuan baku mutu air minum yang berlaku di Provinsi Sumatra Utara, yakni Peraturan Gubernur Sumatera Utara No.1 Tahun 2009 tentang Baku mutu air Danau Toba di Sumatera Utara ${ }^{(5)}$.

Peraturan Gubernur Sumatera Utara No-1 Tahun 2009 tentang Baku mutu air Danau Toba di Sumatera Utara menjelaskan bahwa status mutu air adalah kondisi kualitas air yang diukur dan atau diuji berdasarkan parameter parameter tertentu dan metoda tertentu. Berdasarkan Pasal 8 klasifikasi dan kriteria Mutu Air Danau Toba adalah sebagai berikut :

1. Kelas I, air yang peruntukannya dapat digunakan untuk air baku air minum, dan atau peruntukan lain yang mempersyaratkan mutu air yang sama dengan kegunaan tersebut.

2. Kelas II, air yang peruntukannya dapat digunakan untuk prasarana/sarana rekreasi air, pembudidayaan ikan air tawar, peternakan, air untuk mengairi 17 pertanaman, dan atau peruntukan lain yang mempersyaratkan mutu air yang sama dengan kegunaan tersebut.

3. Kelas III, air yang peruntukannya dapat digunakan untuk pembudidayaan ikan air tawar, peternakan, air untuk mengairi pertamanan, dan atau peruntukan lain yang mempersyaratkan mutu air yang sama dengan kegunaan tersebut.

4. Kelas IV, air yang peruntukannya dapat digunakan untuk mengairi pertanaman dan atau peruntukan lain yang mempersyarat kan mutu air yang sama dengan kegunaan tersebut.

Setiap golongan sumber air tersebut mempunyai karakteristik sendiri-sendiri, namun karena Kelas I dan Kelas II ditujukan langsung dengan kebutuhan primer manusia maka Kelas I dan Kelas II umumnya mempunyai nilai lebih ketat daripada golongan lainnya, utamanya pada parameter-parameter logam berat.

\subsection{Parameter Fisik.}

Tabel-1 menunjukkan bahwa pada saat pengambilan sampel, suhu air Danau Toba berkisar antara $26,3-26,6^{\circ} \mathrm{C}$. Kisaran tersebut adalah kisaran yang biasa terjadi di daerah tropis. Sementara itu konsentrasi TDS berkisar antara 76-80 mg/l dan TSS berkisar antara 1-4 $\mathrm{mg} / \mathrm{L}$. Handayani melaporkan bahwa TDS di 3 lokasi tersebut berkisar antara 1,02-1,42 mg/l dan TSS berkisar antara 8,3-11,0 mg//(6). Konsentrasi TDS dan TSS di Tahun 2016 dan 2017 tersebut jauh lebih kecil dari maksimum konsentrasi yang diperkenankan (baku mutu) yakni $1000 \mathrm{mg} / \mathrm{L}$ untuk TDS dan $50 \mathrm{mg} / \mathrm{l}$ untuk TSS $^{(5)}$ Hal ini mengisaratkan bahwa perairan Danau Toba belum tercemar oleh TSS dan TDS.

\subsection{Kimia Non-Logam.}

Pada Bulan September 2017 pH air Danau Toba berkisar antara 7,54-7,97 (Tabel 2). Kisaran nilai tersebut mengisaratkan bahwa air Danau Toba termasuk sumber air yang netral; tidak basa dan tidak asam sehingga dalam proses pengolahan air bakunya tidak memerlukan perlakuan khusus untuk menurunkan atau menaikan nilai keasaman.

Pada waktu dan tempat yang sama, nilai BOD perairan Danau Toba di 3 lokasi tersebut berkisar antara 5,5 - 6,1 mg/l dan COD antara 44,3 - 341,1 mg/l. Nilai-nilai konsentrasi tersebut lebih tinggi daripada baku mutu yang berlaku, dimana untuk BOD air Kelas I besarnya $2 \mathrm{mg} / \mathrm{l}$ dan Kelas II besarnya $3 \mathrm{mg} / \mathrm{l}$, maupun untuk COD air Kelas I besarnya 2 mg/l dan Kelas II besarnya $3 \mathrm{mg} / /^{(5)}$. Ini mengisyaratkan bahwa air Danau Toba mengandung bahan organik yang tinggi atau perairan Danau Toba tercemar oleh bahan organik. Fenomena ini diduga disebabkan oleh limbah KJA, baik dari sisa pakan maupun kotoran ikan $^{(7,8)}$. Nilai BOD dan COD yang tinggi tidak dikehendaki karena untuk mendegradasi bahan organik yang dikandungnya diperlukan oksigen yang besar, yang jika berlebihan dan berkelanjutan dapat menyebabkan penurunan konsentrasi oksigen terlarut dalam badan air.

Penurunan konsentrasi oksigen terlarut dalam badan air dapat mengganggu respirasi biota air. Pada penelitian ini, nampaknya fenomena tersebut tidak terjadi dimana meskipun nilai BOD dan COD cukup tinggi namun konsentrasi oksigen terlarut di tempat yang sama juga tinggi, yakni $6,3-7,1 \mathrm{mg} \mathrm{O} / \mathrm{l}$. Konsentrasi oksigen terlarut yang nampaknya tidak terpengaruh oleh nilai BOD dan COD yang tinggi tersebut, tidak berarti bahwa dalam perairan tersebut tidak terjadi degradasi organik yang menggunakan oksigen terlarut; namun lebih menunjukkan bahwa oksigen terlarut hasil dari fotosintesa dalam perairan tersebut lebih besar daripada keperluan oksigen untuk mendegradasi organik di dalam BOD dan $\operatorname{COD}^{(9)}$.

Dugaan suplai oksigen yang tinggi dari hasil fotosintesa tersebut diatas, didukung oleh kenyataan bahwa konsentrasi nitrogen dan fosfor dalam perairan tersebut juga tinggi. Tabel2 menunjukkan bahwa konsentrasi total fosfat berkisar antara 0,04-0,06 $\mathrm{mg} \mathrm{P} / \mathrm{l}$ dan total 
nitrogen (jumlah ammonia- $\mathrm{N}$, nitrat- $\mathrm{N}$ dan Nitrit$\mathrm{N})$ berkisar antara 0,158-0,286 mg N/L. Publikasi yang ada mengungkapkan bahwa badan air yang mengandung fosfat $>0,010 \mathrm{mg} P / l$ dan total nitrogen inorganik $>0,300 \mathrm{mg} \mathrm{N} / \mathrm{l}$ baik kedua-duanya atau salah satunya adalah perairan yang berpotensi untuk mengalami "blooming" fitoplankton ${ }^{(10)}$. Hal ini mengisyarat kan bahwa perairan Danau Toba di 3 lokasi tersebut sewaktu waktu dapat mengalami "blooming" algae, yang untuk Danau Toba harus dihindari karena dampaknya dapat menurunkan minat wisata air.

Tabel 2. Parameter fisik dan kimia pada air waduk Danau Toba.

\begin{tabular}{|c|c|c|c|c|c|c|}
\hline \multirow{2}{*}{$\begin{array}{c}\text { Parameter } \\
\text { Fisik }\end{array}$} & \multirow[t]{2}{*}{ Satuan } & \multicolumn{3}{|c|}{ Tempat Pengambilan Sampel (TPS) } & \multicolumn{2}{|c|}{ Baku Mutu } \\
\hline & & TPS-1 & TPS-2 & TPS-3 & Ks-I & Ks-II \\
\hline Temperature $^{*}$ & ${ }^{\circ} \mathrm{C}$ & 26,6 & 26,3 & 26,3 & Dev-3 & Dev-3 \\
\hline TDS* & $\mathrm{mg} / \mathrm{l}$ & 78 & 80 & 76 & 1,000 & 1000 \\
\hline TSS* & $\mathrm{mg} / \mathrm{l}$ & 4 & 1 & 3 & 50 & 50 \\
\hline Kimia Non Logam & & TPS-1 & TPS-2 & TPS-3 & Ks-I & Ks-II \\
\hline $\mathrm{pH}^{*}$ & & 7,97 & 7,89 & 7,54 & 9-Jun & 9-Jun \\
\hline BOD & $\mathrm{mg} / \mathrm{l}$ & 6,1 & 5,5 & 42,6 & 2 & 3 \\
\hline COD & $\mathrm{mg} / \mathrm{l}$ & 48,44 & 44,3 & 341,1 & 10 & 25 \\
\hline $\mathrm{DO}^{*}$ & $\mathrm{mg} / \mathrm{l}$ & 6,3 & 7,1 & 7,1 & 6 & 4 \\
\hline Total $-\mathrm{P}^{*}$ & $\mathrm{mg} / \mathrm{l}$ & 0,060 & 0,050 & 0,040 & 0,2 & 0,2 \\
\hline $\mathrm{NO}_{3}-\mathrm{N}^{*}$ & $\mathrm{mg} / \mathrm{l}$ & $<0,1$ & 0,1 & 0,1 & 10 & 10 \\
\hline $\mathrm{NH}_{3}-\mathrm{N}^{*}$ & $\mathrm{mg} / \mathrm{l}$ & $<0,054$ & 0,130 & 0,186 & 0,5 & \\
\hline $\mathrm{NO}_{2}-\mathrm{N}^{*}$ & $\mathrm{mg} / \mathrm{l}$ & $<0,004$ & $<0,004$ & $<0,004$ & 0,05 & 0,06 \\
\hline $\mathrm{H}_{2} \mathrm{~S}^{*}$ & $\mathrm{mg} / \mathrm{l}$ & $<0,0007$ & $<0,0007$ & $<0,0007$ & 0,002 & 0,002 \\
\hline Sulphate, $\mathrm{SO}_{4}$ & $\mathrm{mg} / \mathrm{l}$ & 0,57 & 3,70 & 0,83 & 400 & - \\
\hline Kimia Logan Berat & & TPS-1 & TPS-2 & TPS-3 & Ks-I & Ks-II \\
\hline $\mathrm{Mn}^{*}$ & $\mathrm{mg} / \mathrm{l}$ & $<0,007$ & $<0,007$ & $<0,007$ & 0,1 & - \\
\hline Copper, $\mathrm{Cu}^{*}$ & $\mathrm{mg} / \mathrm{l}$ & $<0,006$ & $<0,006$ & $<0,006$ & 0,02 & 0,02 \\
\hline $\mathrm{Cr}^{6+*}$ & $\mathrm{mg}$ & $<0,001$ & 0,002 & 0,010 & 0,05 & 0,05 \\
\hline Lead, $\mathrm{Pb}^{*}$ & $\mathrm{mg} / \mathrm{l}$ & 0,001 & 0,001 & 0,001 & 0,03 & 0,03 \\
\hline Arsen, As & $\mathrm{mg} / \mathrm{l}$ & $<0,01$ & $<0,01$ & $<0,01$ & 0,05 & 1 \\
\hline Cobalt, $\mathrm{Co}^{*}$ & $\mathrm{mg} / \mathrm{l}$ & $<0,020$ & $<0,020$ & $<0,020$ & 0,2 & 0,2 \\
\hline Barium, $\mathrm{Ba}^{*}$ & $\mathrm{mg} / \mathrm{l}$ & 0,875 & 0,951 & $<0,277$ & 1 & - \\
\hline Boron, $\mathrm{B}^{*}$ & $\mathrm{mg} / \mathrm{l}$ & 0,2 & 0,2 & 0,4 & 1 & 1 \\
\hline Selenium, Se & $\mathrm{mg} / \mathrm{l}$ & $<0,006$ & $<0,006$ & $<0,006$ & 0,01 & 0,05 \\
\hline Cadmium, $\mathrm{Cd}^{*}$ & $\mathrm{mg} / \mathrm{l}$ & 0,0092 & $<0,00004$ & 0,0002 & 0,01 & 0,01 \\
\hline Mercury, $\mathrm{Hg}^{*}$ & $\mathrm{mg} / \mathrm{l}$ & $<0,00009$ & $<0,00009$ & $<0,00009$ & 0,001 & 0,002 \\
\hline Iron, $\mathrm{Fe}^{*}$ & $\mathrm{mg} / \mathrm{l}$ & 0,841 & 0,841 & 1,036 & 0,3 & - \\
\hline Zinc, $\mathrm{Zn}^{*}$ & $\mathrm{mg} / \mathrm{l}$ & 0,208 & 0,021 & 0,022 & 0,05 & 0,05 \\
\hline Chloride, $\mathrm{Cl}^{-*}$ & $\mathrm{mg} / \mathrm{l}$ & 9,45 & 7,96 & 7,96 & 600 & - \\
\hline Cyanide, $\mathrm{CN}^{*}$ & $\mathrm{mg} / \mathrm{l}$ & $<0,002$ & $<0,002$ & $<0,002$ & 0,02 & 0,02 \\
\hline Fluoride, $\mathrm{F}^{-*}$ & $\mathrm{mg} / \mathrm{l}$ & 0,777 & 0,4 & 0,337 & 0,5 & 1,5 \\
\hline Free- $\mathrm{Cl}_{2}{ }^{*}$ & $\mathrm{mg} / \mathrm{l}$ & 0,1 & 0,1 & 0,1 & 0,03 & 0,03 \\
\hline Oil and Grease ${ }^{*}$ & $\mu g / L$ & $<1000$ & $<1000$ & $<1000$ & 1000 & 1000 \\
\hline Fenol $^{*}$ & $\mu \mathrm{g} / \mathrm{L}$ & $<0,002$ & $<0,002$ & $<0,002$ & 1 & 1 \\
\hline Surfactants & $\mu \mathrm{g} / \mathrm{L}$ & $<0,014$ & $<0,014$ & $<0,014$ & 200 & 200 \\
\hline Biologi & & TPS-1 & TPS-2 & TPS-3 & Ks-I & Ks-II \\
\hline Total Coliform & $\mathrm{Jml} / 100$ & 12 & 90 & 50 & 1000 & 5000 \\
\hline Fecal Coliform & $\mathrm{mL}$ & 12 & 90 & 50 & 100 & 1000 \\
\hline
\end{tabular}


Selanjutnya Tabel 2 menunjukkan bahwa konsentrasi sulfat berfluktuasi pada kisaran antara $0,57-3,70 \mathrm{mg} \mathrm{SO} 4 / \mathrm{l}$, sedangkan sulfida stabil pada konsentrasi yang lebih kecil di 0,0007 $\mathrm{mg} \mathrm{S} / \mathrm{l}$. Kedua parameter tersebut relatif sangat kecil dibandingkan dengan konsentrasi maksimum yang diijinkan (baku mutu). Sehinga karenanya berdasarkan kandungan sulfur yang dikandungnya, peruntukan air Danau Toba untuk air baku air bersih dan wisata air tidak menjadi masalah.

Saat penelitian dilakukan kandungan deterjen di Danau Toba berkisar antara < 0,014 MBAS. Konsentrasi tersebut jauh lebih kecil dari baku mutu yang berlaku yakni 0,5 MBAS, yang menunjukkan bahwa air Danau Toba tidak tercemar oleh deterjen.

\subsection{Parameter Logam Berat}

Logam berat adalah logam yang memiliki nomor atom besar, yang berbahaya bagi kehidupan bila konsentrasinya melebihi baku mutu. Termasuk di dalamnya adalah unsur-unsur $\mathrm{Pb}, \mathrm{Cd}, \mathrm{Cu}$, selenium, arsen, air raksa, dan kromium. Di alam logam berat ditemukan dalam jumlah yang kecil dan umumnya ditemukan dalam bentuk senyawa dengan sulfida atau kompleks mineral yang terdiri dari oksigen, silika dan sulfur. Selain itu logam berat ditemukan pula sebagai hasil sampingan dari kegiatan penambangan, seperti kadmium (Cd) yang ditemukan pada proses pencairan seng ${ }^{(11)}$. Sesungguhnya dalam jumlah tertentu logam berat diperlukan bagi kehidupan akan tetapi dalam jumlah yang melebihi batas yang diperlukan logam berat akan menggangu kehidupan, bahkan dapat mematikan.

Keberadaan logam-logam berat seperti mangan , tembaga , kromium , kadmium dan timbal dalam suatu badan air, apalagi badan air yang dijadikan sumber bahan baku air minum dapat membahayakan kesehatan manusia yang memanfaatkannya. Konsentrasi mangan terlarut di 3 TPS Danau Toba wilayah Tobasa tercatat selalu lebih kecil daripada 0,007 mg/l. Konsentrasi ini masih jauh dibawah konsentrasi maksimum yang diijinkan, yakni $0,100 \mathrm{mg} / \mathrm{l}$; mengisyaratkan bahwa berdasarkan logam mangan yang dikandungnya, air Danau Toba layak digunakan menjadi sumber air baku air minum.

Seperti keberadaan mangan, Tabel-2 juga menunjukkan bahwa di 3 TPS; kandungan logam-logam berikut, yakni tembaga yang lebih kecil dari $0,006 \mathrm{mg} / \mathrm{l}$; khromium yang bervariasi antara 0.001-0.010 mg/l timbal (yang sama 0,001 $\mathrm{mg} / \mathrm{l}$; arsen (yang sama lebih kecil dari $0,01 \mathrm{mg} / \mathrm{L}$; cobalt yang sama lebih kecil dari $0,02 \mathrm{mg} / \mathrm{L}$, Barium yang berkisar antara 0,277-0,951 mg/L,
Boron yang berkisar antara 0,2-0,4 $\mathrm{mg} / \mathrm{l}$; Selenium yang sama lebih kecil dari $0,006 \mathrm{mg} / \mathrm{l}$ Cadmium yang berkisar antara 0,00004-0,0002 $\mathrm{mg} / \mathrm{l}$ dan merkuri yang sama lebih kecil dari $0,0009 \mathrm{mg} / \mathrm{l}$ adalah lebih kecil daripada konsentrasi maksimum masing-masing tersebut yang diijinkan sehingga berdasarkan kandungan logam-logam tersebut, air Danau Toba memenuhi sarat untuk dijadikan air baku air bersih.

Konsentrasi Tembaga yang $0,006 \mathrm{mg} / \mathrm{l}$ dan timbal, yang sama $0,001 \mathrm{mg} / \mathrm{l}$ pada studi ini tercatat lebih kecil dari studi sebelumnya yang melaporkan konsentrasi tembaga berkisar antara 0,020-0,045 mg/l dan timbal antara 0,013-0,0,44 $\mathrm{mg} / \mathrm{l}$. Perbedaan ini diduga disebabkan karena perbedaan tempat pengambilan sampel dan waktu $^{(4)}$

Selanjutnya, Tabel-2 menunjukkan bahwa seng dan besi adalah berbeda dengan logamlogam berat tersebut diatas. Logam berat tersebut diatas memenuhi kriteria kualitas air Kelas I dan Kelas II pada Peraturan Gubernur Sumatera Utara No-1 Tahun 2009 sehingga berdasarkan kandungan logam-logam berat tersebut memenuhi sarat air baku air minum dan wisata air,

Konsentrasi seng di 3 TPS berturut-turut adalah antara $0,21 \mathrm{mg} / \mathrm{l}, 0,021 \mathrm{mg} / \mathrm{l}$ dan 0,022 $\mathrm{mg} / \mathrm{l}$. Dibandingkan dengan konsentrasi maksimum yang diijinkan (baku mutu) untuk Air Kelas I dan Kelas II yakni 0,05 mg/l, konsentrasi seng di TPS-1 lebih besar sedangkan di TPS-2 dan TPS-3 lebih kecil dari baku mutu yang berlaku. Ini mengisaratkan bahwa berdasarkan kandungan seng didalamnya, air Danau Toba belum layak dijadikan air baku air minum. Sementara itu, konsentrasi besi di 3 TPS bervariasi antara 0,841-1,036 mg/l. Konsentrasi besi jauh lebih tinggi daripada konsentrasi maksimum yang diijinkan baik untuk Kelas I maupun Klas Dua. Dengan demikian maka berdasarkan konsentrasi seng dan besi yang ada, air Danau Toba belum memenuhi sarat untuk air baku air minum, dan wisata air.

\section{KESIMPULAN}

Mencermati pembahasan hasil analisis air Danau Toba tersebut diatas maka dapat disimpulkan bahwa karena konsentrasi beberapa parameter; yakni BOD, COD, besi dan klorida ditemukan lebih besar daripada konsentrasi maksimun yang ditetapkan dalam Peraturan Gubernur Sumatera Utara No-1 Tahun 2009 tentang Baku Mutu Air Danau Toba di Sumatera Utara maka perairan Danau Toba tidak/belum layak menjadi air baku air minum dan wisata air. 


\section{PERSANTUNAN}

Penulis mengucapkan terima kasih kepada Badan Otorita Pengelola Kawasan Pariwisata Danau Toba dan Pusat Pelayanan Teknologi BPPT yang telah memberikan dana kajian lingkungan ini.

\section{DAFTAR PUSTAKA}

1. Lukman dan Ridwansyah., 2010: "Kajian Kondisi Morfometri dan Beberapa Parameter Stratifikasi Perairan Danau Toba". Limnotek (2010) 17 (2).

2. Eyanoer F..Sebiring M., Medju Sj. Damanik \& .Anwar, 1980. Laporan Akhir Komunitas Lingkungan Perairan Dan Kehidupan Biologi Danau Toba Sumatera

3. Ruttner, F., 1930. Hydrographische und hydrochemishe Beobachtungen auf Java, Sumatera und Bali. Pp: 196-454. In: A. Thienemann.Archiv fur hydrobiology.Organ Der Internationalen Fur Theoretische und Angewandte Limnologie. Supplement-Band VIII. ESchweizerbart's che Verlagsbuchhandlung (Ewin Nagele) G.m.b.H.Stuttgart.

4. Tampubolon, H.S, D.Bakti, I.Lesmana, 2013. Studi Kandungan Logam Berat Tembaga $(\mathrm{Cu})$ Dan Timbal $(\mathrm{Pb})$ Di Perairan Danau Toba, Provinsi Sumatera Utara (Study Of Heavy Metal Of Copper (Cu) And Lead (Pb) In Lake Toba, North Sumatera Province). Universitas Sumatera Utara.
5. Anonim, (2009) Peraturan Gubernur Sumatera Utara No1 Tahun 2009 tentang Baku mutu air Danau Toba di Sumatera Utara.

6. Handayani T, N.Suwedi, A. Darmawan, A. Riyadi, D. B. Aviantara, R. N. Sopiah, F. Suciati Dan Lain. 2016, Kualitas Air Danau Toba, Laporan Survey Kerjasama Menkomar Dan BPPT.

7. Gultom J. dan P. Panjaitan.(2009) Seminar Nasional Studi dampak Pencemaran pada Lokasi KJA PT.Aquafarm Nusantara. Tuktuk Kabupaten Samosir Januari

8. Rismawati, 2010 Analisis Daya Dukung Perairan Danau Toba Terhadap Kegiatan Perikanan Sebagai Dasar Dalam Pengendalian Pencemaran Keramba Jaring Apung,, Sekolah Pascasarjana Universitas sumatera utara medan

9. Garno, 2002 Y.S (2002): Beban Pencemaran Limbah Perikanan Budidaya dan Yutrofikasi di Perairan waduk pada DAS Citarum. J. Tek. Ling. P3TL-BPPT. 3(2): 112-120

10. Hendersen B. and H.R. Markland (1987): Decaying Lakes-The Origins and Control of Cultural Eutrofication. John \& Willey Sons Ltd. New York Chichester, Brisbane, Toronto, Singapura.. Theor. Angew. Limnol. Verh., 20, 68-74

11.EPA, "Water Quality Criteria," Ecological Res. Series, Washinton, 1972, 595 pp. 